\title{
NANOTUBULAR OXIDE LAYERS FORMED ON THE Ti-BASED IMPLANTS SURFACES-APPLICATION AND POSSIBLE DAMAGES: A REVIEW
}

\author{
Dragana R. Barjaktarević ${ }^{* 1}$, Veljko R. Djokić ${ }^{2}$ Ivana D. Damnjanovićl, \\ Marko P. Rakin ${ }^{1}$ \\ ${ }^{1}$ Faculty of Technology and Metallurgy, University of Belgrade, \\ Karnegijeva 411120 Belgrade, Serbia \\ ${ }^{2}$ Innovation Centre of the Faculty of Technology and Metallurgy, University of \\ Belgrade, Karnegijeva 411120 Belgrade, Serbia
}

Received 30.11.2018

Accepted 17.12.2018

\begin{abstract}
Implant surface properties define the interaction of the implant with the surrounding tissue. To obtained advanced biological, mechanical and physical properties, metallic implants are often exposed to different kinds of surface modification. The electrochemical anodization process is an efficient method for nanostructured surface modification, which leads to the formation of nanotubular oxide layers on metallic surfaces. These obtained layers could be applied in biomedicine due to their chemical stability, biocompatibility and non-toxic nature in the human body. As a part of different kinds of medical implants such as dental implants, artificial hip joints, bone plates, screws, spinal fixation devices or stents, an oxide layer significantly increases cells adhesion and plays a significant role in improving the rate of osseointegration. However, an important topic in research of implants with a nanotubular oxide layer is integrity during fixation and exploitation and possible damage initiation and development. This review article aims to present the application of nanotubular oxide layers in biomedicine and to explain their influence on the biocompatibility and osseointegration of medical implants. Influence of the layers properties, such as roughness or contact angle, and the influence of their morphology on biocompatibility and osseointegration, as well as the influence of fixation and exploitation on the damage of the nanotubular oxide layer, are considered.
\end{abstract}

Keywords: application of nanotubular oxide layer; biocompatibility; damage of nanotubular oxide layer; Ti-based implants; osseointegration.

\footnotetext{
* Corresponding author: Dragana R. Barjaktarević, dbarjaktarevic@tmf.bg.ac.rs
} 


\section{Introduction}

Nanotechnology is defined as a discipline aimed at understanding the properties and application of structures, devices, and systems where the dimensions are less than $100 \mathrm{~nm}[1,2]$. Nanotechnology in medicine can be used for the production of devices, structures, and materials with a positive effect on human health. Some of the applications of nanotechnology in medicine are presented in Fig. 1. Advance uses of nanotechnology are in medical therapy as nanoparticles for antibiotics delivery or vaccines, production of surgical tools and bone replacement materials or stents with a nanostructured layer [1]. For example, one of an important application of nanotechnology in medicine is in the production of devices of nanometers dimension that could be used to target drug delivery to a specific place or as a detector for early stages of disease [3]. The other significant application of nanotechnology in medicine is the production of biomaterials used in orthopedic and dental implants.

Nanotechnology can be used for making nanostructured surfaces of implants that have non-specific adsorption of proteins and could increase the biocompatibility of the materials in the human body [4].

One of the ways to produce a nanostructured implant surface is forming an oxide layer that is made of nanotubes using different methods for the modification of a surface. For example, to obtain a $\mathrm{TiO}_{2}$-based nanotubes template $[5,6]$, the sol-gel process [7], hydrothermal treatment [8,9] and electrochemical anodization [10] could be used. Nanotubes are specifically structured nanoparticles of a defined geometry with nanometre wall thickness, and a significant length to diameter ratio.

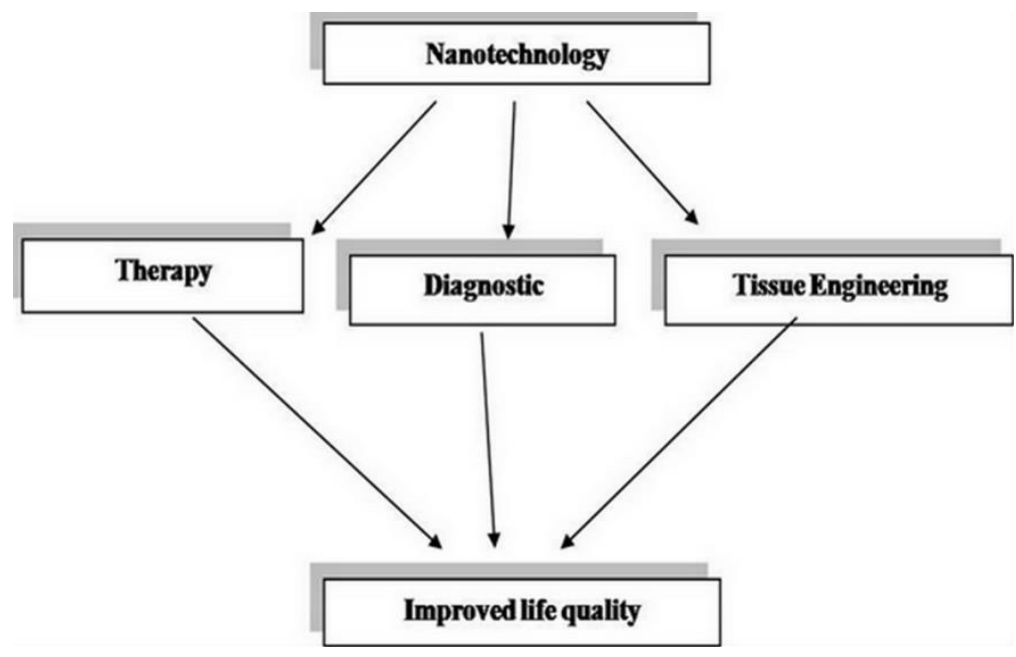

Fig. 1. Application of nanotechnology in medicine [2].

\section{The basis of the nanostructured modification of surfaces of metallic biomaterials}

The main electrochemical surface modification methods used for nanostructured metallic biomaterials are anodization, micro-arc anodization, and electrodeposition [11]. The anodization process is a surface modification method that is usually used in case of titanium-based materials, but anodization can be applied to a large number of metallic 
materials in order to obtain nanostructured surfaces. The equipment for anodization consists of a cell with two or three electrodes: titanium-based materials as the anode and working electrode, platinum as cathode and counter electrode and when the cell has three electrodes, the $\mathrm{Ag} / \mathrm{AgCl}$ electrode is used as a reference electrode [12]. The advantage of the anodization process is the ability to make the nanostructured formation with a direct connection to the substrate. Also, the anodization process can be used to a large and different shape of the substrate (this is the case with an implant) [13]. The disadvantage of the anodization process is the expensive equipment required when the process is applied for very complicated shapes [13].

The most significant advantage of the anodization process is that it can create a homogeneous nanotubular oxide layer. The form of the nanotubular oxide layer and the dimensions of the nanotubes diameter, length and wall thickness may be controlled using the parameters of the anodization process [14-16].

One of the first reports concerning anodization as a method suitable for the formation of self-organized $\mathrm{TiO}_{2}$ nanostructured surfaces on a titanium implant was by Dezfuly et al. [17]. Subsequently, Zwilling et al. [18] showed that the anodization process in an electrolyte containing fluoride ions is an efficient method for obtaining a nanostructured oxide layer on titanium and the titanium alloy Ti-6Al-4V. They varied the conditions of the anodization process and finally concluded that the nanotubular oxide layer was formed at voltages of $5 \mathrm{~V}$ and $10 \mathrm{~V}$ within 20 minutes. The nanotubular oxide layer formed on titanium and titanium alloys have lengths from a few hundred nanometers to up to several micrometers depending on the electrochemical anodization parameters [19-22]. It was shown, that the formation of a $4.4 \mu \mathrm{m}$ thick titanium nanotubular oxide layer is possible using anodization in NaF or KF electrolytes [19] while using ethanol in the presence of HF leads to the formation of $2.3 \mu \mathrm{m}$ long nanotubular oxide layer [20]. Fluoride solutions at a $\mathrm{pH}$ value of 7 create nanotubular oxide layers of $2.5 \mu \mathrm{m}$ [21]. Aguire et al. [23] reported that the nanotubular oxide layer has a thickness of approximately $0.5 \mu \mathrm{m}$ in HF electrolyte, while in the presence of a fluoride salt, such as $\mathrm{NaF}$ or $\mathrm{NH}_{4} \mathrm{~F}$, the thickness of the nanotubular oxide layer doubles.

Low concentrations of fluoride ions in the electrolyte (less than 0.05 wt.\%) lead to the formation of the stable oxide layer. On the contrary, high fluoride ion concentration, around $1 \mathrm{wt} . \%$ does not lead to the formation of an oxide layer because of the direct reaction between $\mathrm{Ti}^{4+}$ and the fluoride ion. Medium concentrations of fluoride ions lead to the creation of a nanoporous structure and a nanotubular oxide layer [24].

Many authors explain the physical formation of the nanotubular oxide layer and their connection to the parameters of the anodization process $[24,25,26]$. They presented a mechanism in which a decrease in the current density occurs due to the formation of a compact oxide film. In the next stage, a random nanoporous structure is formed, and the surface area increases causing the current density to increase. During the second stage, the nanoporous layer progressively dissolves while the layer with formed nanotubes grows. In the last stage, the current density achieves a steady value, which indicates that a nanotubular oxide layer is obtained, Fig. 2. This mechanism of the formation of a nanotubular oxide layer indicates that nanotubes grow with increasing anodizing time. Moreover, nanotubes can grow at various speeds because nanotubes "contest for the current" [26]. For this reason nanotubes in the nanotubular 
oxide layer may have different geometries. When the dissolution of the nanoporous structure is finished, and if metallic materials have been removed from the solution in time, a nanotubular oxide layer can be formed. On the contrary, if the anodization is too long, this will lead to the formation of a nanotubular oxide layer with thin nanotubes walls.
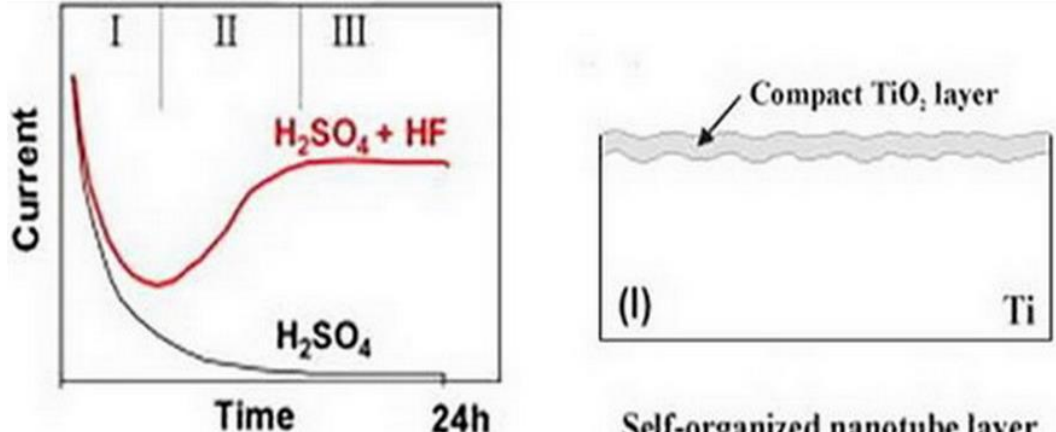

Self-organized nanotube layer

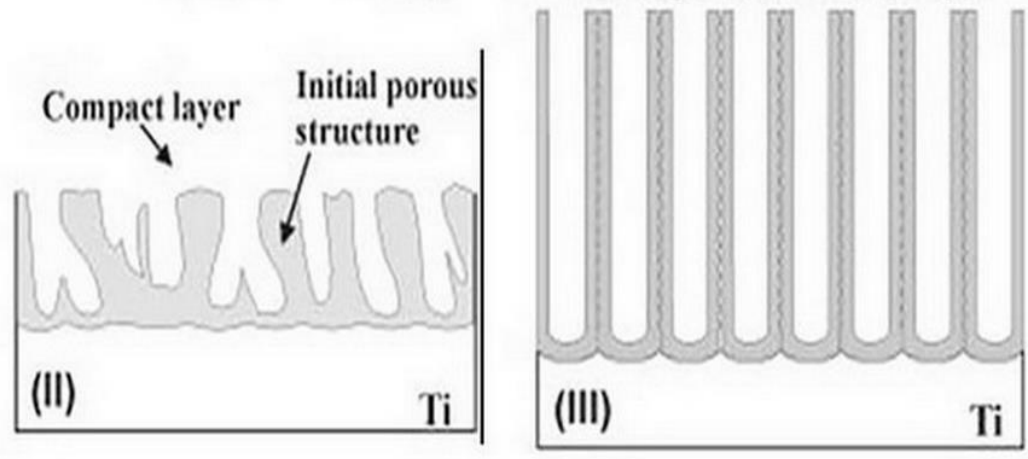

Fig. 2. Representation of the formation of a nanotubular oxide layer [25].

This technology that is used to replace the thin natural oxide layer that forms on the surface of a titanium implant due to exposure to the air present with a thick oxide coating nowadays is complemented and widely used in the production of dental and orthopedic implants. The DOTIZE ${ }^{\circledR}$ technology was developed by DOT America and is one of the first anodization processes applied in the industry of metallic biomaterials. Using the DOTIZE ${ }^{\circledR}$ technology, an oxide layer with a maximal thickness of $5 \mu \mathrm{m}$ is produced, leading to nanoroughness of the implant surfaces and better biocompatibility, increased corrosion and wear resistance and no significant changes in dimensions of Tibased materials are produced [27]. Also, Nobel Biocare ${ }^{\circledR}$ is a commercial dental implant with an anodized surface that is often used in clinical testing [28, 29]. One of the possible titanium anodizing systems in the manufacture of medical device consists of a few general steps, as shown in Fig. 3 [30]. First, materials are placed in a cleaner tank, and then they are rinsed. Subsequently, the materials are etched in a selected solution, with the immersion time depending on the aggressiveness of the solution and then completely rinsed. The tank anodizing step includes the presence of a voltage and current. The time of this step can be longer if there are holes in the implant as they are less assessable. After the process time, the materials are removed and rinsed. 


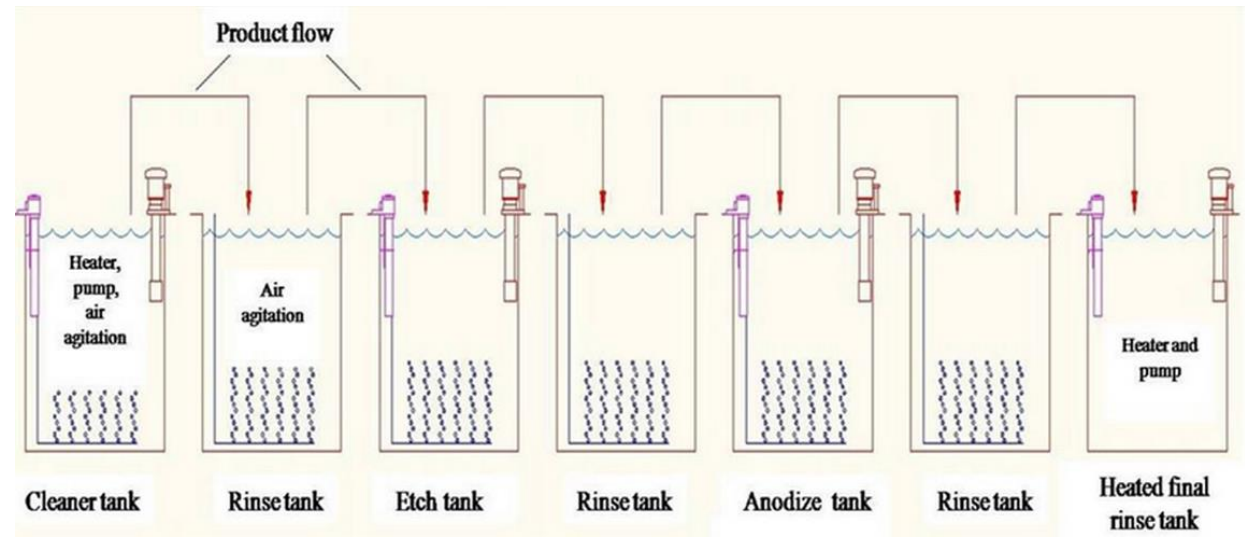

Fig. 3. System and general steps of the anodization process [30].

\section{Application of nanotubular oxide layers as biomaterials}

$\mathrm{TiO}_{2}$ based nanotubes can be used in different biomedicine application due to their chemical stability, biocompatibility and non-toxic properties in the human body, Fig. 4 [31].

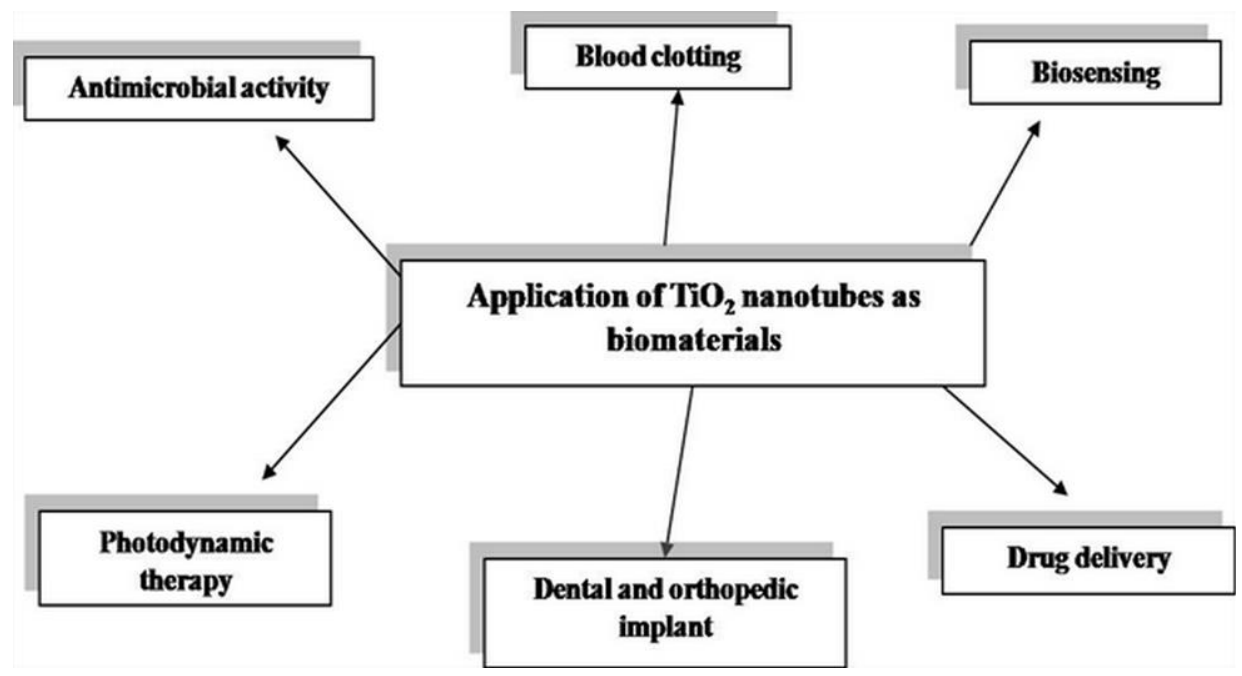

Fig. 4. Applications of $\mathrm{TiO}_{2}$ based nanotubes [31].

Titanium and especially titanium alloys are some of the most used metallic biomaterials in tissue engineering because they have excellent biocompatibility and osseointegration $[32,33]$. Osseointegration is a phenomenon that refers to the formation of a structural and functional connection between the bone and an implant, whereby a bone-implant complex is formed as a single entity [34]. Factors that have an impact on the osseointegration process are the shape of the implant, the chemical composition of the implant material, the presence of a coating and the state of the implant surface. 
Reactions between implant materials and tissue depend on the surface topography and properties of the implant, an implant with a rough surface showing faster osseointegration than a smooth surface [35]. Natural tissues, such as extracellular matrix proteins, minerals, and pore in membranes, have nanometer dimensions and for this reason, many papers consider that nanostructured surface modification of biomaterials might improve the growth and interaction of tissue cells [1]. A nanostructured surface enhances integration with the surrounding tissue because, as stated by the authors, of rapid deposition of calcium [36-38].

There are two essential factors in a better response of human cells to an implant with a nanotubular oxide layer: increased surface roughness and extraordinary hydrophilicity [39]. An implant surface with a larger surface area, produced by the spacing between nanotubes, offers a suitable implant-cells connection. Yu et al. [40] showed that a nanotubular oxide layer with nanotubes of diameters between $0 \mathrm{~nm}$ and $120 \mathrm{~nm}$ creates a surface roughness of between $0 \mathrm{~nm}$ and $46.54 \mathrm{~nm}$, while a nanotubular oxide layer has contact angles with water of $0^{\circ}$, which is more hydrophilic than a smooth Ti surface with a contact angle of $80^{\circ}$. Figure 5 shows that the formation of a nanotubular oxide layer increases the roughness of the surface, but increasing the diameter of the nanotubes does not make significant changes in the surface roughness. On the other hand, the anodization process on the titanium surface decreases the contact angle, and this decrease is more significant with nanotubes of larger diameter.

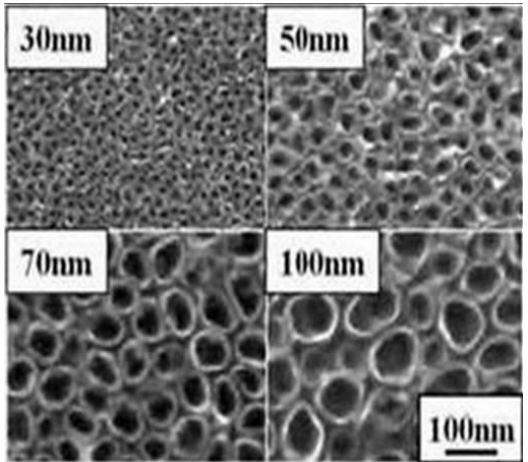

\begin{tabular}{lllll}
\hline Sample & $\begin{array}{l}\text { Applied } \\
\text { voltage } \\
(\mathrm{V})\end{array}$ & $\begin{array}{l}\text { Nanotube } \\
\text { diameter } \\
(\mathrm{nm})\end{array}$ & $\begin{array}{l}\text { Roughness } \\
R \\
(\mathrm{~nm})\end{array}$ & $\begin{array}{l}\text { Contact } \\
\text { angle } \\
\left({ }^{\circ}\right)\end{array}$ \\
\hline $\mathrm{Ti}$ & 0 & 0 & 0 & 54 \\
30 & 5 & 27 & 13 & 11 \\
50 & 10 & 46.4 & 12.7 & 9 \\
70 & 15 & 69.5 & 13.5 & 7 \\
100 & 20 & 99.6 & 13.2 & 4 \\
\hline
\end{tabular}

Fig. 5. Nanotubes dimension and its influence on the roughness and hydrophilicity [39, 41].

Many papers compared the adhesion and growth of human cells for different morphologies of nanotubular oxide layers and different nanotubes diameters. Thus, Brammer et al. [41] showed that the anodization process, unrelated the diameter of the 
nanotubes, increased number of cell, and the viability of the cells, while increasing the nanotube diameter to around $100 \mathrm{~nm}$, the elongation of the cells will significantly increase. It was shown that extraordinary cell elongation is present on nanotubes with diameters of $70 \mathrm{~nm}$ and $100 \mathrm{~nm}$, and advanced elongation starts when the nanotube diameter is increased from $30 \mathrm{~nm}$ to $50 \mathrm{~nm}$ [42]. However, a larger diameter has an impact on cell elongation of their body. On the other hand, increased nanotube diameters lead to decreasing cell adhesion, which occurs because of increasing empty space between the nanotubes, while this larger space can enhance cell spreading [42, 43]. The in vitro tests confirm that the best adhesion of the cells is when the diameter of $\mathrm{TiO}_{2}$ nanotubes is less than $100 \mathrm{~nm}$ [44]. Park et al. [45] created a nanotubular oxide layer with nanotubes of diameter in the range from $15 \mathrm{~nm}$ to $100 \mathrm{~nm}$ and performed in vivo tests. They showed that a nanotubular oxide layer with nanotubes diameter of 15 $\mathrm{nm}$ leads to increased cell adhesion, cell proliferation, and cell viability compared to a smooth surface. On increasing the nanotube diameter to between $15 \mathrm{~nm}$ to $50 \mathrm{~nm}$, the cell adhesion, cell proliferation, and cell viability start to reduce. While, on increasing the nanotube diameter to between $50 \mathrm{~nm}$ to $100 \mathrm{~nm}$, the cell adhesion, cell proliferation, and cell viability are significantly reduced. Figure 6 presents the influence of the nanotube diameter on the cell adhesion, cell proliferation, cell elongation, and protein absorption.

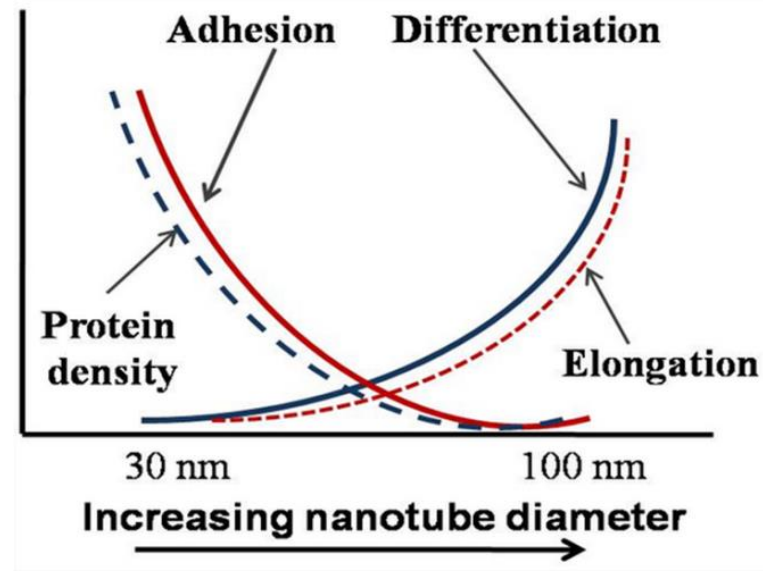

Fig. 6. Influence diameter of the nanotube on the behavior of the cells [42].

The authors of the present article worked on the formation of a nanotubular oxide layer on ultrafine-grained commercially pure titanium (UFG cpTi) and ultrafine-grained Ti-13Nb-13Zr (UFG TNZ) alloy, which was obtained using a high-pressure torsion process (HPT). In a previous study, nanotubular oxide layers were formed on the surfaces of TNZ and UFG TNZ alloy using electrochemical anodization during 90 minutes [46]. The obtained results show that the adhesion of human MRC-5 and animal L929 fibroblast cells significantly improved, while the cytoplasm extensions made very good contact with a nanotubular oxide layer formed on the surface of the alloys, and this was more observable for a nanotubular oxide layer on the UFG TNZ alloy for both cell types. Oh et al. [47] estimated the rate of cell adhesion on a titanium surface with a nanotubular oxide layer obtained during 30 minutes. The results showed that a 
nanotubular oxide layer with nanotubes of a diameter of $70 \mathrm{~nm}$ showed better cell adhesion then titanium before the anodization process.

Furthermore, the dimension of the nanotubes influences protein absorption. It was shown that nanotubes with a diameter of $30 \mathrm{~nm}$ lead to the distribution of a larger quantity of protein particles that overspread the entire surface of the nanotubular oxide layer. Nanotubes with a diameter of $100 \mathrm{~nm}$ lead to protein molecules rarely attaching to the top of the nanotubes walls, because the empty space between the nanotubes is larger when the nanotube diameter is larger [48].

To estimate the osseointegration rate and the behavior of the surface, Moon et al. [49] removed titanium implant screws from animal models after implantation and concluded that the contact of an implant with the surrounding bone is significantly higher after formation of a nanotubular oxide layer, as presented in Fig. 7. Eun-Ju et al. [50] compared the osseointegration rate of a Ti-6Al-4V implant with and without a nanotubular oxide layer 3 and 6 weeks after implantation. They concluded that a nanotubular oxide layer formed on the implant surface leads to improved bioactivity, biomechanical and bone regenerative properties.
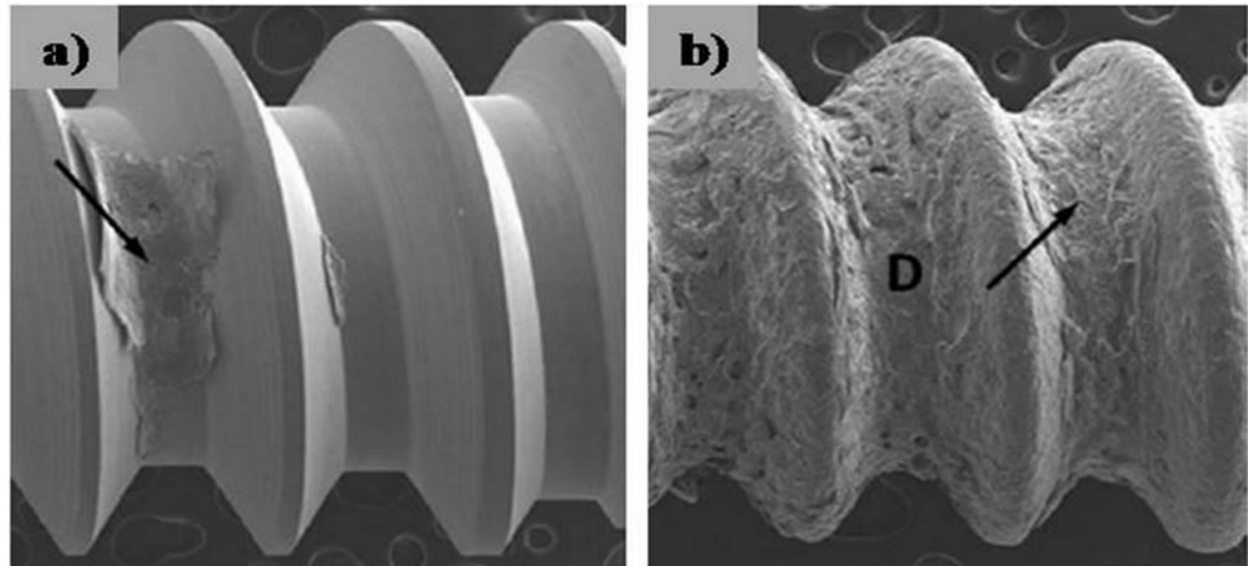

Fig. 7. Removed implant from an animal model, (a) non-anodized surface, (b) anodized surface [49].

The lower value of the modulus of elasticity and closer to that of surrounding tissue is one of the main factors in reducing the possibility of structural damage to the bone in contact with the implant and in accepting the material after implantation [51]. The formation of a nanotubular oxide layer on the implant surface could decrease the elasticity modulus values ranging from $23 \mathrm{GPa}$ to $34 \mathrm{GPa}$ [52]. In this way, the modulus elasticity values are reduced and thus approach the bone tissue values (10-30 GPa) [53]. The modulus elasticity value depends on the nanotubular oxide layer morphology and nanotubes dimensions. It was shown that the modulus elasticity values decreased with increasing the thickness of the nanotubular oxide layer [54]. Crawford et al. [55] showed that by increasing the time of anodization process from $0.25 \mathrm{~h}$ to $4 \mathrm{~h}$, the thickness of the nanotubular oxide layer increased, but at the same time, lead to decreasing the value of the modulus elasticity from $7.2 \mathrm{GPa}$ down to 4.6 GPa, respectively. Xu et al. [56] investigated the modulus of elasticity of the nanotubular 
oxide layer formed of $\mathrm{TiO}_{2}$ nanotubes using the nanoindentation technique. They concluded that the modulus elasticity value of materials with nanotubular oxide layers was lower compared to smooth materials. With increased displacement in the nanoindentation test, the substrate influence on the modulus elasticity values was higher. Zielinski et al. [57] showed that the formation of the nanotubular oxide layer with a nanotubes diameter ranging from $80 \mathrm{~nm}$ to $120 \mathrm{~nm}$ and a length of $1 \mu \mathrm{m}$ on the Ti-13Nb-13Zr alloy decreased the modulus elasticity value down to $25.5 \mathrm{GPa}$. The modulus elasticity value of the commercially pure titanium after the nanotubular oxide layer formation was reduced from 127.5 GPa to $46.18 \mathrm{GPa}$ [58].

To show the enhanced rate of osseointegration and contact between surrounding tissues and nanostructured modified surface implant, and potential applications of a titanium nanotubular oxide layer in tissue engineering, many authors did tests in animal models. A detailed overview of already published research results regarding the effect of a nanotubular oxide layer on a Ti-based implant on the integration with the surrounding tissue is given in Table 1.

Table 1. The effects of a nanostructured surface of Ti-based materials on the integration with the surrounding tissue [28, 29, 35, 59-64].

\begin{tabular}{|c|c|c|c|}
\hline Reference & Implant & $\begin{array}{l}\text { Nanotubular oxide layer } \\
\text { morphology }\end{array}$ & Obtained research results \\
\hline $\begin{array}{l}\text { 1. Jungner } \\
\text { et al. [28] }\end{array}$ & $\begin{array}{l}\text { Titanium } \\
\text { dental } \\
\text { implant }\end{array}$ & $\begin{array}{l}\text { Commercial implants with } \\
\text { anodized surfaces Nobel } \\
\text { Biocare } ® \text {. }\end{array}$ & $\begin{array}{l}\text { Results show a } 100 \% \text { success } \\
\text { rate of the implants with an } \\
\text { anodized surface compared to a } \\
\text { success rate of } 96.4 \% \text { with } \\
\text { implants with a smooth surface. }\end{array}$ \\
\hline $\begin{array}{l}\text { 2. Jungner } \\
\text { et al. [29] }\end{array}$ & $\begin{array}{l}\text { Titanium } \\
\text { dental } \\
\text { implant }\end{array}$ & $\begin{array}{l}\text { Commercial implants with } \\
\text { anodized surfaces (MKIII, } \\
\text { Ti Unite, Nobel Biocare } \\
\text { AB). }\end{array}$ & $\begin{array}{l}\text { After } 5 \text { years of use, non- } \\
\text { anodized implants and anodized } \\
\text { implants show success rates of } \\
94.7 \% \text { and } 99.4 \% \text {, respectively. } \\
\text { The results show no significant } \\
\text { differences. }\end{array}$ \\
\hline $\begin{array}{l}\text { 3. Young- } \\
\text { Ah Yi et } \\
\text { al. }[35]\end{array}$ & $\begin{array}{l}\text { Titanium } \\
\text { femur } \\
\text { bone } \\
\text { implant }\end{array}$ & $\begin{array}{l}\text { The Ti nanotubular oxide } \\
\text { layers had nanotube } \\
\text { diameters of } 30 \mathrm{~nm}, 50 \\
\mathrm{~nm}, 70 \mathrm{~nm} \text {, and } 100 \mathrm{~nm} \text {. }\end{array}$ & $\begin{array}{l}\text { The implant with nanotubes of } \\
\text { diameter } 30 \mathrm{~nm} \text { had larger } \\
\text { formed bone around the implant } \\
\text { than the implant with nanotubes } \\
\text { diameter of } 70 \mathrm{~nm} \text {, after two } \\
\text { weeks. After six weeks, the } \\
\text { implant with nanotubes of } \\
\text { diameter } 70 \mathrm{~nm} \text { had larger formed } \\
\text { bone around the implant. }\end{array}$ \\
\hline $\begin{array}{l}\text { 4. Lin et } \\
\text { al. [59] }\end{array}$ & $\begin{array}{l}\text { Titanium } \\
\text { screw } \\
\text { implant }\end{array}$ & $\begin{array}{l}\text { The Ti nanotubular oxide } \\
\text { layer had an average } \\
\text { nanotube diameter of } 78 \\
\text { nm. (obtained at } 20 \mathrm{~V} \\
\text { during } 20 \text { minutes). }\end{array}$ & $\begin{array}{l}\text { The results show that a } \\
\text { nanostructured surface had better } \\
\text { osseointegration when Ti screws } \\
\text { were implanted in New Zealand } \\
\text { white rabbits. }\end{array}$ \\
\hline
\end{tabular}




\begin{tabular}{|c|c|c|c|}
\hline Reference & Implant & $\begin{array}{l}\text { Nanotubular oxide layer } \\
\text { morphology }\end{array}$ & Obtained research results \\
\hline $\begin{array}{l}\text { 5. Cheng } \\
\text { et al. [60] }\end{array}$ & $\begin{array}{l}\text { Titanium } \\
\text { bone } \\
\text { implant }\end{array}$ & $\begin{array}{l}\mathrm{Ti} \text { nanotubular oxide } \\
\text { layers had an average } \\
\text { nanotube diameter of } 30 \\
\mathrm{~nm} \text { and } 80 \mathrm{~nm} \text {, formed at } \\
10 \mathrm{~V} \text { or } 40 \mathrm{~V} \text { loaded with } \\
\mathrm{Ag} \text { and } \mathrm{Sr} \text {. }\end{array}$ & $\begin{array}{l}\text { Antibacterial activity and } \\
\text { enhanced cell adhesion, viability, } \\
\text { and proliferation were obtained. }\end{array}$ \\
\hline $\begin{array}{l}\text { 6. Nuhn et } \\
\text { al. [61] }\end{array}$ & $\begin{array}{l}\text { Ti-6Al- } \\
4 \mathrm{~V} \\
\text { stent }\end{array}$ & $\begin{array}{l}\text { The Ti-based nanotubular } \\
\text { oxide layers had an } \\
\text { average nanotubes } \\
\text { diameter of } 90 \pm 5 \mathrm{~nm} \text { and } \\
\text { length of } 1800 \pm 300 \mathrm{~nm} \text {. }\end{array}$ & $\begin{array}{l}\text { Lower rates of stenosis for the } \\
\text { titanium-based stents with a } \\
\text { nanotubular oxide layer. }\end{array}$ \\
\hline $\begin{array}{l}\text { 7. Jang et } \\
\text { al. [62] }\end{array}$ & $\begin{array}{l}\text { Titanium } \\
\text { screw } \\
\text { implant }\end{array}$ & $\begin{array}{l}\text { The Ti-based nanotubular } \\
\text { oxide layers had an } \\
\text { average nanotube } \\
\text { diameter of } 70 \mathrm{~nm} \text { and } \\
\text { length of } 5 \mu \mathrm{m} \text {. }\end{array}$ & $\begin{array}{l}\text { The nanotubular oxide layer on } \\
\text { the surface of the screw } \\
\text { improved the rate of } \\
\text { osseointegration and stability of } \\
\text { the implant. }\end{array}$ \\
\hline $\begin{array}{l}\text { 8. Kubo et } \\
\text { al. [63] }\end{array}$ & $\begin{array}{l}\text { Titanium } \\
\text { bone } \\
\text { implant }\end{array}$ & $\begin{array}{l}\text { Nanopores with diameters } \\
\text { of } 100 \mathrm{~nm}, 300 \mathrm{~nm} \text {, and } \\
500 \mathrm{~nm} \text {, and micro-pores } \\
\text { obtained at the implant } \\
\text { surface. }\end{array}$ & $\begin{array}{l}\text { Integration with animal tissue } \\
\text { was three times greater for the } \\
\text { implants with } 300 \mathrm{~nm} \text { nano-pores } \\
\text { than the implants with micro- } \\
\text { pores. }\end{array}$ \\
\hline 9. Sul [64] & $\begin{array}{l}\text { Titanium } \\
\text { screw } \\
\text { implant }\end{array}$ & $\begin{array}{l}\text { The nanotubular oxide } \\
\text { layers had average } \\
\text { nanotube diameters of } 90 \\
\mathrm{~nm} \text { for } 30 \text { minutes, } 107 \\
\mathrm{~nm} \text { for one hour and } 108 \\
\mathrm{~nm} \text { for three hours. }\end{array}$ & $\begin{array}{l}\text { A titanium nanotubular oxide } \\
\text { layer led to significantly } \\
\text { increased osseointegration and } \\
\text { formation of new bone around } \\
\text { the implant. }\end{array}$ \\
\hline
\end{tabular}

The nanotubular oxide layer formed using the electrochemical anodization process on titanium-based materials could be used for more efficient and exact drug delivery than conventional methods [65]. Nanotubes lead to the enhanced maximum amount of drug and extended drug release [66], but the morphology of the nanotubes formed on the surfaces influences the drug amount. For example, a nanotubular oxide layer with 10-20 nm space between nanotubes increased the capacity and surface area [39]. Yao et al. [67] demonstrated the use of a nanotubular oxide layer formed on the surface of titanium as a drug delivery system. They concluded that a system with penicillin could be successfully used for the release of a drug and had improved bone cell adhesion. Popat et al. [68] investigated the delivery of the antibiotic gentamycin from a nanotubular oxide layer formed on the surface of a titanium implant, and they concluded that this way of drug delivery provides greater safety from infection after implant surgery. Balasundaram et al. [69] investigated osteoblast adhesion between a smooth titanium surface and a nanotubular oxide layer with and without protein-2. They concluded that the anodization process increased the roughness of surfaces, which 
increases cell adhesion, but an excellent cell adhesion was obtained after immobilized protein-2 in nanotubes.

\section{Damages of the nanotubular oxide layer on an implant surface}

A special topic in the research of implants with a nanotubular oxide layer is their integrity during fixation and exploitation, as well as possible damage initiation and development. In many studies, damage to the nanotubular oxide layer formed on the implant surface was observed using different testing methods, such as tribological, micro scratch, nanoindentation $[55,70,71]$ and control stability of the nanotubular oxide layer on the implant surface after implantation in animal models. Shemtov-Yona et al. [72] studied the damage to the surface of nanostructured titanium and Ti-6Al-4V dental implants after removal from the tissue. This study shows that the examined implants with an anodized surface could be without damage. It was shown that the nanotubular oxide layer formed on titanium screws was damaged and removed at the edge of the screw, while other parts of the implant screw retained the nanotubular structure, which had good interaction with animal tissue, Fig. 8 [62].
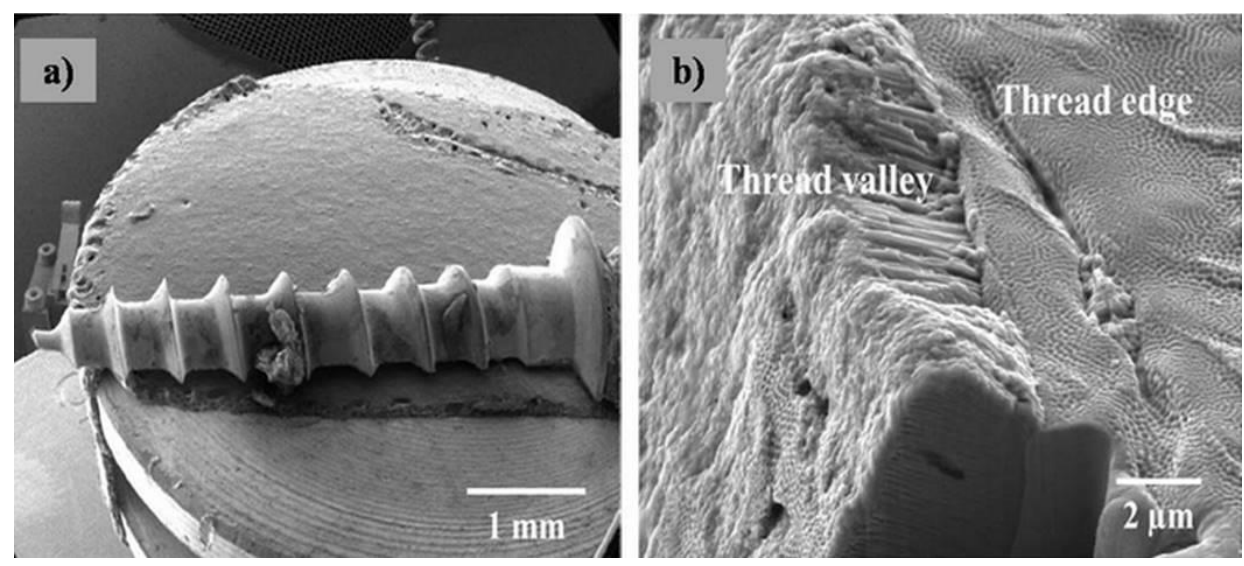

Fig. 8. Screw implant after test in the animal model (a) and damage of the nanotubular oxide layer (b) [62].

As can be seen in Fig. 9, critical positions (shown with arrows) for damage of the nanotubular oxide layer are the edges of the titanium implant screw [73]. 

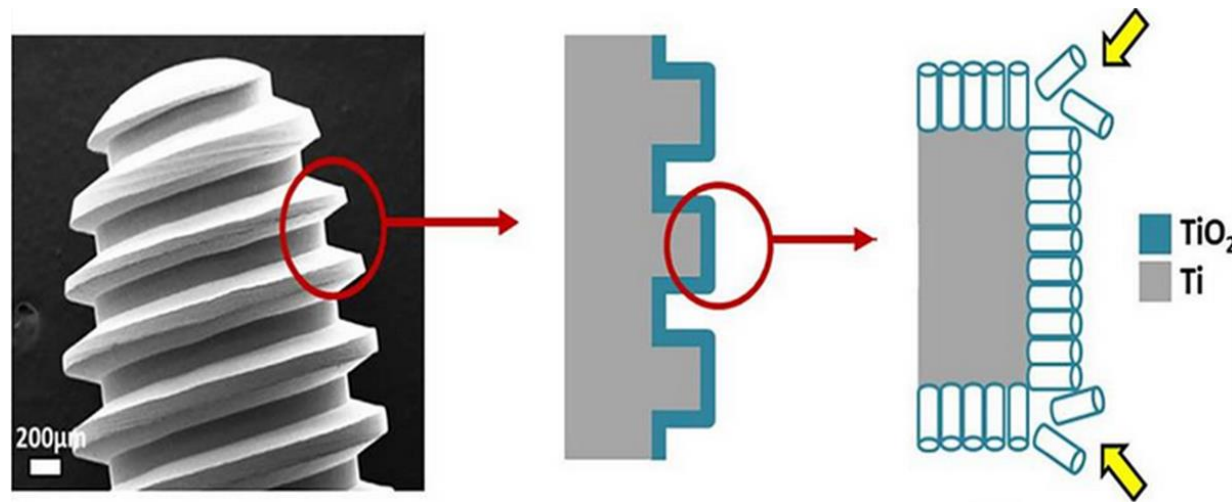

Fig. 9. Schematic presentation of the critical position for damage of a nanotubular oxide layer [73].

On the other hand, Shivaram et al. [74] showed that no damage of the nanotubular oxide layer with a length of up to $1 \mu \mathrm{m}$ was visible after implantation.

One of the procedures during the implantation that can lead to the damage of the nanotubular oxide layer is sterilization, more precisely autoclaving of implants under high temperatures and pressures [25]. Shivaram et al. [75] tested damage of the nanotubular titanium surface after exposure to various high temperatures. They concluded that shorter nanotubes, $300 \mathrm{~nm}$ in length, show damage at $400{ }^{\circ} \mathrm{C}$, but temperature of $700{ }^{\circ} \mathrm{C}$ lead to total damage of the nanotubes. Similarly, longer nanotubes, $950 \mathrm{~nm}$ in length, showed damage at $500{ }^{\circ} \mathrm{C}$, while total damage to the layer was evidenced at $700{ }^{\circ} \mathrm{C}$.

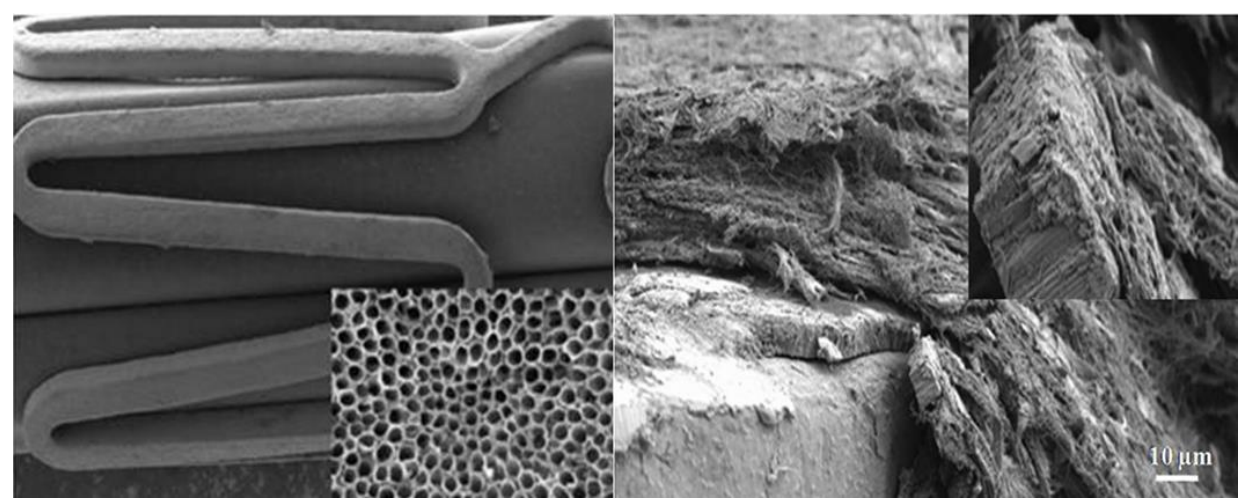

Fig. 10. The nanotubular oxide layer on the surface of titanium stent and its damage [61].

The insertion of a dental implant could result in an intense change in the stress field, which indicates that the implant does not interact with a bone over the entire surface. This fact has a significant influence on damage evolution of the implant surface, has been reported [76]. A nanotubular oxide layer formed on a Ti-based stent was damaged during the implantation but was still connected to the surrounding tissue, 
which indicates a strong interaction between the tissue and nanostructured implant surface, as presented in Fig. 10 [61].

In the human body, implants are exposed to different kinds of external loads, which could provoke cyclic stress. Variation in stress could lead to damage to part of the implant surface. Chen et al. [77] stated that the nanotubular oxide layer on the implant surface formed by electrochemical anodization does not change the life duration of the implant exposed to fatigue [77], despite damage to the nanotubular oxide layer after cyclic stress. Different nanostructured surface modification methods exhibit various behaviors of the implants during fatigue. Thus, the acid etching method reduces fatigue durability, while a combination of the surface modification methods of blasting and acid etching lead to the same fatigue durability as that of a non-modified implant [78]. The human body, which is composed of saline solution with a $\mathrm{pH}$ value of 7 (in special cases, such as cancer or infection, the $\mathrm{pH}$ value can be lower) is a corrosive environment, which could lead to damage of the implants. The nanotubular oxide layer of an implant is corrosion resistant, which is also an important factor because it leads to a reduction in corrosion damage of the implant $[79,80,81]$. Also, a reduction in the corrosion damage could be achieved using a high-pressure torsion process, as authors of this paper showed in a previous study [82].

\section{Conclusions}

Electrochemical anodization process, which is used to replace the thin natural oxide layer that forms on the surface of a titanium implant due to exposure to the air with a thick nanoporous or nanotubular oxide layer, is nowadays complemented and widely used in the production of dental and orthopedic implants. The nanotubular oxide layers formed on titanium and titanium alloys have a length of up to several micrometers and a homogenous morphology. To obtain longer layers, acid or salt in the presence of fluoride is used. A medium fluoride ion concentration, (around 0.5 wt. \%) leads to the formation of a nanoporous structure and nanotubular oxide layer. When nanotubular oxide layers are used on medical implants, two important factors for better response of human cells exit, i.e., increased surface roughness and extraordinary hydrophilicity. It was shown that this oxide layer increases the roughness of the surface, but increasing the diameter of the nanotubes does not induce significant changes in surface roughness.

On the contrary, the hydrophilicity increased with increasing nanotubes diameter. Nanotubular oxide layers could be used for different kinds of implants and, after tests in animal models; they showed enhanced rates of osseointegration and greater contact with the surrounding tissues, independent of the nanotubes dimension. On the other hand, nanotubular oxide layers could be damaged from the implants during the implantation process, but this fact does not change the possibility of their application in biomedicine because of their positive effects.

\section{Acknowledgments}

The authors greatly acknowledge the financial support of the Ministry of Education, Science and Technological Development of the Republic of Serbia through the projects ON 174004 and III 45019. 


\section{References}

[1] M. Zaki, Nanotechnology and Advances in Medicine, Nova Science Publishers, 2011.

[2] C. Schmidt, J. Storsberg: Biomedic, 3 (2015) 203-223.

[3] M. Obradović, S. Miljković, L .Matija, J. Munćan, Đ. Koruga: Sec. Cong. of Doc. of Med., Serbia, Book of Abstract, (2011) 1-12.

[4] M. Goldberg, R. Langer, X. Jia: J Biomater Sci Polymer Edn, 18 (2007) 241268.

[5] J .Jung, H. Kobayashi, C. van Bommel, S. Shinkai, T. Shimizu: Chem Mater, 14 (2002) 1445-1447.

[6] J. Lee, C. Leu, C. Hsu , W. Chung, H. Hon: J Phys Chem B, 109 (2005) 13056-13059

[7] T. Kasuga, M. Hiramatsu, A. Hoson, T. Sekino, K. Niihara: Langmuir, 14 (1998) 3160-3163.

[8] S. Zhang, W. Li, Z. Jin, J. Yang, J. Zhang, Z. Du, Z. Zhang: J Solid State Chem, 177 (2004) 1365-1371.

[9] C. Tsai, N. Nian, H. Teng: Appl Surf Sci, 253(2006) 1898-1902.

[10]D. Barjaktarević, I. Cvijović-Alagić, I. Dimić, V. Đokić, M. Rakin: Metall Mater Eng, 22 (2016) 129-143.

[11] A. Gao, R. Hang, L. Bai, B. Tang, P. K. Chu: Electrochem Acta, 271 (2018) 699-718.

[12] D. Portan, G. Papanicolaou, G. Jiga, M. Caposi: J Appl Electrochem, 42 (2012) 1013-1024.

[13] M. Kulkarni, A. Mazare, E. Gongadze, Š. Perutkova, V. Kralj-Iglič, I. Milošev, P. Schmuki, A. Iglič, M. Mozetič: Titanium Nanotech, 26 (2015) 1-18.

[14] K. Kim, N. Ramaswamy: Dent Mater J, 28 (2009) 20-36.

[15] J. Hernández-López, A. Conde, J. Damborenea, M.A. Arenas: Corr Sci, 112 (2016) 194-203.

[16] A. Tan, B. Pingguan-Murphy, R. Ahmad, S. Akbar: Ceramics Inter, 38 (2012) $4421-4435$

[17] M. Assefpour-dezfuly, C. Vlachos, E. Andrews: J Mater Sci, 19 (1984) 36263639.

[18] V. Zwilling, E. Darque-Ceretti, A. Boutry-Forveille, D. David, M. Perrin, M. Aucouturier: Surf Interface Anal, 27 (1999) 629-637.

[19] Q. Cai, M. Paulose, K. Varghese, A. Grimes: J of Mater Res, 20 (2005) 230236.

[20] C. Ruan, M. Paulose, M., K. Varghese, K. Mor, A. Grimes: The J of Phys Chem B, 109 (2005) 15754-15759.

[21] M. Macak, H. Tsuchiya, P. Schmuki, P. Angewandte: Chem Inter Edition, 44 (2005) 7463-7465.

[22] A. Ghicov, H. Tsuchiya, M. Macak, P. Schmuki: Electrochem Comm, 7 (2005). 505-509.

[23] R. Aguirre, F. Echeverria: Appl Surf Sci, 445 (2018), 308-319.

[24] P. Roy, S. Berger, P. Schmuki: Chem Int Ed, 50 (2011) 2904-2939.

[25] T. Li, K. Gulati, N. Wangc Z. Zhang, S. Ivanovski: Mater Sci Eng C, 88 (2018) 182-195.

[26] H. Tsuchiya, J. Macak, A. Ghicov, Y. Tang, S. Fujimoto, M. Niinomi, T. Noda, P. Schmuki: Electroch Acta, 52 (2006) 94-101. 
[27]DOT America, High-Tech Surfaces to Enhance Device Performance http://www.dot-coatingusa.com/ Accessed 12 December 2018.

[28] M. Jungner, P. Lundqvist, S. Lundgren: Clin Oral Impl Res, 16 (2005) 308312.

[29] M. Jungner, P. Lundqvist, S. Lundgren: Clin Imp Dent Rel Res, 16 (2014) 230237.

[30] Titanium Anodizing Equipment \& Information for Professionals http://anodizetitanium.com/ Accessed 12 December 2018.

[31] N. Kumar, N. Chauhan, A. Mittal, S. Sharma: Biometals, 31 (2018) 147-159.

[32] S. Prasad, M. Ehrensberger, M. Gibson, H. Kim, E. Monaco: J of Oral Biosci, 57 (2015) 192-199.

[33] R. Aguirre, M. Echeverry, D. Quintero, J. Castano, M. Harmsen, S. Robledo, F. Echeverr: J Biomed Mater Part A, 106 (2018) 1341-1354.

[34] P. Branemark, R. Adell, T. Albrektsson, U. Lekholm, S. Lundkvist, B. Rockler: Biomater, 4 (1983) 25-28.

[35] Y. Yi, Y. Park, H. Choi, K. Lee, S. Kim, K. Kim, S. Oh, J. Shim: J of Nanomater, (2015) 1-11.

[36] T. Webster, C. Ergun, R. Doremus, R. Siegel, R. Bizios: Biomater, 21 (2000) 1803-1810.

[37] N. Ergun, J. Liu, T. Webster, E. Olcay, S. Yilmaz, F. Sahin: J Biomed Mater Res Part A, 85 (2008) 236-241.

[38] C. Yao, E. Slamovich, T. Webster: J Biomed Mater Res Part A, 85 (2008) 157166.

[39] K. Brammer, C. Frandsen, S. Jin: Trend in Biotechn, 30 (2012) 315-322.

[40] W. Yu, X. Jiang, F. Zhang, L. Xu: J Biomed Mater Res Part A, 94 (2010) $1012-1022$.

[41] K. Brammer, S. Oh, C. Cobb, L. Bjursten, H. Heyde, S. Jin: Acta Biomater, 5 (2009) 3215-3223.

[42] S. Oh, K. Brammer, Y. Li, D. Teng, A. Engler, S. Chien, S. Jin: PNAS, 106 (2009) 2130-2135.

[43] D. Khudhair , A. Bhatti, Y. Li , H. Hamedani, H. Garmestani, P. Hodgson, S. Nahavandi: Mater Sci Engin, C 59 (2016) 1125-1142.

[44] S. Minagar, J. Wang, C. Berndt, E. Ivanova, C. Wen: J Biomed Mater Res Part A, 101 (2013) 2726-2739.

[45] J. Park, S. Bauer, K. Mark, P. Schmuki: Nano Lett, 7 (2007)1686-1691.

[46] D. Barjaktarević, Đ. Veljović, I. Dimić, V. Đokić, M. Rakin: Conf Advan Ceram Applic VII, Book of Abstracts, 2018, p. 85, https://www.sanu.ac.rs/wpcontent/uploads/2018/08/ELMINA-2018-BoA.pdf.

[47] S. Oh, C. Daraio, L. Chen, T. Pisanic, R. Fĩnones, S. Jin: J of Biomed Mater Res Part A, 78 (2006) 97-103.

[48] K. Brammer, S. Oh, C. Frandsen, S. Jin: Biomater Sci Engin, 405 (2011) 193211.

[49] S. Moon, S. Lee, I. Park, M. Lee, Y. Soh, T. Bae, H. Kim: Biomed Mater Res Part B, 100 (2012) 2053-2059.

[50]E. Oh, T. Nguyen, S. Lee, Y. Jeon, T. Bae, J. Kim: The Kor J Orthod, 44 (2014) 246-253.

[51] A. Ossowska, S. Sobieszczyk, M. Supernak, A. Zielinski: Sur \& Coat Techn, 258 (2014) 1239-1248. 
[52] T. Shokuhfar, G. Arumugam, P. Heiden, R. Yassar, C. Friedrich, ACS Nano, 3 (2009) 3098-3102.

[53] Y. Bai, Y. Deng, Y. Zheng, Y. Li, R. Zhang, Y. Lv, Q. Zhao, Sh. Wei: Mater Sci and Eng C, 59 (2016) 565-576.

[54] G. Crawford, N. Chawla, J. Houston: J Mech Behav Biomed Mater, 2 (2009) $580-587$.

[55] G. Crawford, N. Chawla, K. Das, S. Bose, A. Bandyopadhyay: Acta Biomater. 3 (2007) 359-367.

[56] Y. Xu, M. Liu, M. Wang, A. Oloyede, J. Bell, C. Yan: J of Appl Phys, 118 (2015) 145301-145307.

[57] A. Zielin'ski, P. Antoniuk, K. Krzysztofowicz: Surf Eng 30 (2014) 643-648.

[58] S. Alves, A. Rossi, A. Ribeiro, F. Toptan, A. Pinto, T. Shokuhfar, J. Celis, L. Rocha: J of the Mech Behav of Biomed Mater 80 (2018) 143-154.

[59] L. Lin, H. Wang, M. Ni, Y. Rui, T. Cheng, C. Cheng, X. Pan, G. Li, C. Lin: J of Orthop Transl, 2 (2014) 35-42.

[60] H. Cheng, W. Xiong, Z. Fang, H. Guan, W. Wu, Y. Li, Y. Zhang, M. Alvarez, B. Gao, K. Huo, J. Xu, N. Xu, C. Zhang, J. Fu, A. Khademhosseini, F. Li: Acta Biomater. 31 (2016) 388-400.

[61] H. Nuhn, C. Blanco, T. Desai: Appl Mater Interfaces, 9 (2017) 19677-19686.

[62] I. Jang, S. Shim, D. Choi, B. Cha, J. Lee, B. Choe, W. Choi: Biomed Microdev, 17 (2015) 76-83.

[63] K. Kubo, N. Tsukimura, F. Iwasa, T. Ueno, L. Saruwatari, H. Aita: Biomater, 30 (2009) 5319-329.

[64] Y. Sul: Int J Nanomed, 5 (2010) 87-100

[65] Q. Wang, J. Huang, H. Li, A. Zhao, Y. Wang, K. Zhang, H. Sun, Y. Lai: Inter J of Nanomed, 12 (2017) 151-164.

[66] L. Yang, B. Sheldon, T. Webster: American Ceram Soc Bull, 89 (2010) 24-32.

[67] C. Yao, T. Webster: J of Biomed Mater Res Part B: Appl Biomater, 91(2009) 587-595.

[68] K. Popat, M. Eltgroth, T. Tempa, C. Grimes, T. Desai: Biomater, 28 (2007) 4880-4888.

[69] G. Balasundaram, C. Yao, T. Webster: J of Biomed Mater Res Part A, 84 (2008) 447-453.

[70] S. Alvesa, A. Rossic, A. Ribeirob, F. Toptana, A. Pintoa, J. Celisg, T. Shokuhfari, L. Rochaa: Wear, 384 (2017) 28-42.

[71] M. Sarra, B. Razak1, R. Crum, C. Gámez, B. Ramirez, N. Hayaty, B. Kasim, B. Nasiri-Tabriz, V. Gupta, N. Sukiman, W. Basirun: Process Appl Ceram, 11 (2017) 311-321.

[72] K. Yonan, D. Rittel: J Mech Beh Biomed Mater, 49 (2015) 290 - 299.

[73] T. Li, K. Gulati, N. Wang, Z. Zhang, S. Ivanovski: J of Coll and Interface Sci, 529 (2018) 452-463.

[74] A. Shivaram, S. Bose, A. Bandyopadhyay: J Mech Beh Biomed Mater, 59 (2016) $508-518$.

[75] A. Shivaram, S. Bose: A Surf Sci 317 (2014) 573-580.

[76] D. Mints, C. Elias, P. Funkenbusch., L. Meirelles: Int J Oral Maxillofac Implant, 29 (2014) 97-104.

[77]Z. Chen, W. Wang, Y. Takao, T. Matsubara, L. Ren: Appl Surf Sci, 262 (2012) 2-7. 
[78] L. Pazosa, P. Corengia, H. Svoboda: J Mech Beh Biomed Mater, 3 (2010) 416424.

[79] E. Urbańczyk, A. Krząkała, A. Kazek-Kęsik, J. Michalska, A. Stolarczyk, G. Dercz, W. Simka: Surf \& Coat Technol, 291 (2016) 79-88.

[80] A. Al-Swayih: Orient J Chem, 32 (2016) 2841-2856.

[81] V. Saji, H. Choe: Corr Sci, 51 (2009) 1658-166.

[82]D. Barjaktarević, J. Bajat, I. Cvijović-Alagić, I. Dimić, A. Hohenwarter, V. Đokić, M. Rakin: Proceedings of ECF22-Loading and Environmental effects on Structural Integrity, 2018, p. 494, http://www.ecf22.rs/docs/Book\% 20of\%20 Abstracts\%20ECF22.pdf.

\section{(c) $\underset{\mathrm{EY}}{(\mathbf{7})}$ Creative Commons License}

This work is licensed under a Creative Commons Attribution 4.0 International License. 